\title{
VIOLENCE AGAINST WOMEN AND CARE PRACTICE IN THE PERCEPTION OF THE HEALTH PROFESSIONALS
}

\author{
Ethel Bastos da Silva1, Stella Maris de Mello Padoin², Lucila Amaral Carneiro Vianna ${ }^{3}$
}

${ }^{1}$ Ph.D. in Sciences. Adjunct Professor of the Department of Health Sciences of the Federal Universidade Federal de Santa Maria (UFSM). Santa Maria, Rio Grande do Sul, Brazil. E-mail: ethelbastos@hotmail.com

${ }^{2}$ Ph.D. in Nursing. Adjunct Professor of the Department of Nursing, UFSM. Santa Maria, Rio Grande do Sul, Brazil. E-mail: padoinst@smail.ufsm.br

${ }^{3}$ Ph.D. in Public Health. Full Professor of the Universidade Federal de São Paulo. São Paulo, State of São Paulo, Brazil. E-mail: lvianna13@gmail.com

\begin{abstract}
This study sought to investigate and analyze the conceptions of professionals from family health teams regarding violence against women and care practice, through participant research, undertaken in a city located in the northwest region of the state of Río Grande do Sul, Brazil. A total of 30 professionals participated, in eight meetings, involving a process of reflection and learning, held in September - December 2012. The data were analyzed using content analysis. The professionals understand that violence against women exists due to the hierarchy and the relationships between men and women, which confers more power on men, a situation which legitimates male practice of violence. The care practice is based on a biological conception of the problem, with a tendency to the social. The care is directed towards the treatment of physical injuries, listening, guidance, denunciation, and referral to specialized health departments and the social service.
\end{abstract}

DESCRIPTORS: Violence against women. Health personnel. Family health. Care.

\section{VIOLÊNCIA CONTRA A MULHER E A PRÁTICA ASSISTENCIAL NA PERCEPÇÃO DOS PROFISSIONAIS DA SAÚDE}

\begin{abstract}
RESUMO: Buscou-se conhecer e analisar as concepções de profissionais das equipes de saúde da família em relação à violência contra a mulher e à prática assistencial, por meio da pesquisa participante, desenvolvida em uma cidade localizada na região Noroeste do estado do Rio Grande do Sul. Participaram trinta profissionais, em oito reuniões, que se constituíram em um processo de reflexão e aprendizagem, nos meses de setembro a dezembro de 2012. Os dados foram analisados por conteúdo temático. Os profissionais compreendem que a violência contra a mulher existe devido à hierarquia nas relações entre homens e mulheres, que confere mais poder ao homem, situação que o legitima a praticar a violência. A prática assistencial parte de uma concepção biológica do problema com tendência à social. Os cuidados direcionam-se ao tratamento da lesão física, escuta, orientação à denúncia e encaminhamento a setores especializados de saúde e assistência social.
\end{abstract}

DESCRITORES: Violência contra a mulher. Pessoal de saúde. Saúde da família. Assistência.

\section{VIOLENCIA CONTRA LA MUJER Y LA PRÁCTICA ASISTENCIAL EN LA PERCEPCIÓN DE LOS PROFESIONALES DE LA SALUD}

\begin{abstract}
RESUMEN: Se ha buscado conocer y analizar las concepciones de profesionales de los equipos de salud de la familia, con relación a la violencia contra la mujer y a la práctica asistencial, por medio de la Pesquisa Participante desarrollada en una ciudad ubicada en la región noroeste del Estado de Rio Grande do Sul. Participaron treinta profesionales en ocho reuniones que se constituyeron de un proceso de reflexión y aprendizaje durante los meses de septiembre a diciembre de 2012. Los datos fueron analizados por contenido temático. Los profesionales comprenden que la violencia contra la mujer existe debido a la jerarquía en las relaciones entre hombres y mujeres en que se le confiere más poder al hombre, situación que lo legitima a practicar dicha violencia. La práctica asistencial parte de una concepción biológica del problema con tendencia a la social. Los cuidados se dirigen hacia el tratamiento de la lesión física, escucha, orientación a la denuncia y encaminamiento a los sectores especializados de salud y asistencia social.
\end{abstract}

DESCRIPTORES: Violencia contra la mujer. Personal de salud. Salud de la familia. Asistencia. 


\section{INTRODUCTION}

Violence against women is defined as that which causes them suffering and abuse due to the condition of being women. This characterization directs the problem to a gender construction, because the situations experienced by the women are particular to the female class, constructed in the relationships between men and women in the society in which they are inserted. ${ }^{1}$

In terms of prevalence, one study undertaken with low-income populations around the world reveals that one in three women will experience physical or sexual violence from an intimate or non-intimate partner. ${ }^{2}$

In Brazil, according to data from the Brazilian Women's Yearbook of 2011, 43.1\% of the women had suffered violence in their own home, and among all the women attacked inside or outside the house, $25.9 \%$ of the aggressors were their husbands or ex-husbands. ${ }^{3}$

Violence against women provokes consequences to mental and reproductive health, ${ }^{2}$ and these implications contribute to increasing attendances by women in the health services, which are shown to have little resolutive capacity, causing high costs to the health system. ${ }^{4}$

Primary Health Care (PHC), represented by the Family Health Strategy (ESF) is one of the privileged locales for attending violence against women as a health need in a social perspective. ${ }^{4}$ The program for Integrated Women's Healthcare (PAISM) encompasses actions in this area, ${ }^{5}$ however, the effort of the public policies, for implementing attendances of cases of violence against women in the health services, has not led to significant impact on the professionals' care practice. The ESF professionals have knowledge of situations of violence against women in their areas and intervene in the treatment of injuries and symptoms. ${ }^{6}$

The reasons for the existence of biologistic and fragmented care practices arise from: the professional training; the organization of the Unified Health System (SUS), which, even with a discourse which covers social and cultural questions, has practices centered on the biologistic model; and on the professionals' lack of qualification and institutional support, and on the lack of a multidisciplinary team. ${ }^{5}$

International studies revealed that the professionals select the women to follow and justify this conduct by the high workload, the lack of support from the managers for the professionals, the low number of health workers, the lack of time available for listening, and lack of knowledge in areas such as mental health and the legal area. ${ }^{7-8}$

Just as there are traditional care practices which maintain the invisibility of the violence in the services, there are also those which value the intersubjective relationships and allow transformations in the life of the women undertaken in an integrated way with the health services and other complementary departments. ${ }^{9-10}$

The way in which the professionals understand the health problem defines how it will be resolved and determines the care practice. ${ }^{4-6}$ This being the case, this study aims to investigate and analyze the conceptions of professionals from family health teams in relation to violence against women and to care practice.

\section{METHOD}

This is a qualitative study in which participatory research (PR) was adopted as the method. PR is social research with an empirical base, considered, planned and undertaken in association with an action or resolution of a collective problem, in this case violence against women, in which the researcher and the professionals find themselves involved with the question and interact cooperatively and participatively in search of how to advise women who suffer violence. With this purpose, investigation, education and action were articulated. ${ }^{11}$

The methodological phases for the production of the empirical data for the construction of the educational workshops were organized in accordance with the phases proposed by Le Boterf, ${ }^{12}$ described in sequence below.

\section{Institutional and methodological assembly of the participative research}

This was constituted of three meetings with representatives of the Municipal Health Department and the Coordinator of the Family Health Strategy and representatives of the Municipal Board of Management for presenting the study, obtaining the letter of authorization, and referring the project to the Research Ethics Committee (REC). Following the REC's approval, a schedule of activities required to take place in eight meanings was elaborated, and the place, date and time were arranged, along with the techniques for production of the empirical data and the research participants. The locale chosen for the meetings was the headquarters of the Specialist Center for Worker's Health (CEREST). 
Professionals participated from the six Family Health Teams (EqSF), made up of nurses, physicians, nursing technicians, auxiliary nurses, dentists, oral health assistants and community health workers. The six units of the ESF totaled 65 professionals, who were invited to participate in the study. The inclusion criteria adopted were to be a professional of the EqSF and to be undertaking activities. In the participative research, the qualitative criteria for the sample was based in the conception of the group regarding the issue investigated. In each meeting, the number of participants varied in number and category. The professionals were released from their duties in order to participate in the study.

\section{Preliminary and provisional study of the zone and population studied}

In the first meeting, the Introductory Seminar was undertaken, the presentation of the study and the Free and Informed Consent form was undertaken, and the latter were handed over for signing and returning. Following that, the socio-demographic questionnaire was distributed for filling out. Afterwards, the participants, 41 professionals, were divided into five groups for initiating the discussions, with the inductive questions: "What do you understand by violence?" and "How do you attend the women who experience a situation of violence in their reality?" The technique of elaborating posters was used for this activity, with the oral presentation of the summary of the discussion of each group.

\section{Critical analysis of the problems considered prioritary, and which the researchers wish to study, and of the study objectives}

In the second meeting, the situations which limit and strengthen the care practice for the women in situations of violence were identified and discussed, with the participation of 31 professionals; in the third meeting, with the participation of 33 professionals, the problems (limitations), causes of the violence, solutions and actions for confronting the violence were debated.

\section{Scheduling and undertaking of a plan of action}

In the fourth meeting, with 29 participants, the problem of the practice was elaborated, and the pedagogical action was organized, with the defining of issues to be studied. In the fifth meeting, with 34 participants, the following issue was debated: Recognition of the violence against women, besides the biological dimension. In the sixth meeting, with 18 participants, the following issue was discussed: Embracement and approaching women in situations of violence. In the seventh meeting, with 33 participants, the following issue was problematized: An integrated care network for the women in situations of violence. In the eighth meeting, the final seminar took place, in which 28 participants made an evaluation of the learning and of the transformations perceived in the care practice, the point at which the research activities were closed.

The empirical data were produced in the months of September to December 2012, and were recorded and transcribed in each phase of the method.

The project was approved by the Ethics Committee of the Universidade Federal de São Paulo, under Opinion N. 51866/2012. So as to maintain anonymity, it was decided to identify each participant with the letter $\mathrm{P}$ followed by a number in accordance with the order of participation, representing the idea of the individual, and RG for the group's rapporteur, followed by the order of presentation, representing the idea of the group.

The empirical data which emerged were subjected to thematic content analysis. ${ }^{13}$ In this study, the participants' accounts were transcribed, read numerous times, and classified as record units. Those which have the same meaning were grouped, and were given units of meaning, as they represented the same thematic content. At the second point, the units of meaning and the record units were read again and re-grouped, in two categories: Gender violence, with the subcategories: Relationships of Inequality and Absence of support when requested; and Care practice for the woman in a situation of violence, with the subcategories: Beginning with biological care and Psychosocial care.

\section{RESULTS AND DISCUSSION}

In order to understand violence against women and care practice, in the perception of the health professionals, the study presents gender violence as an analytical category in the cycle of violence against women, and the influence of the conception of social, historical, economic and cultural construction of gender, in its occurrence, 
revealing these professionals' view of the violence against women. In the plan of the practices, it is sought to analyze the care model in which the professionals operate in confronting gender violence, discussing what is stipulated in the field of policy and what is undertaken in practice. In these perspectives, the results allow one to analyze these professionals' conceptions in the dimensions of gender violence and care model.

\section{Gender violence}

From the analysis of the data undertaken in accordance with the revealing category Gender violence, mentioned above, the subcategory of Relationships of inequality is presented. It was observed that the professionals of the EqSF, of this study, reported that in the socio-affective relationships, the woman is frequently submissive to the man, and that he has authority over her, which is presented in the account below.

Speaking about this business of the man being stronger, we thought this was very interesting: the man is my general. Often, the woman thinks that she owes obedience to the man and remains silent about much that the man says and does (P1-RG1).

The women, subjected to a system of socialization which weakens and disqualifies them, tend to learn attitudes of abnegation, resignation and silence. The relationships between the sexes in the public and private spaces are permeated by power asymmetry and by social and cultural elaboration of the female identity, as a passive and dependent woman who gives the man the condition of being the oppressor and dominator. ${ }^{14}$ When the woman lives in a condition of subordination to the man, the violence is aggravated, as this places her in a situation of vulnerability to excessive masculine attitudes, because she is not the subject of her own life. ${ }^{15}$ The idea that the woman is submissive to the man, expressed by the professionals of this study, contributes to the occurrence of violence, which is confirmed in another study which says that inequality in gender relationships is considered a cause of violence against women. ${ }^{5}$

In reflecting on the issue, the professionals of this study say that women, in a resigned way, accept the functions of caring for the house, the children and husband, and work outside the house in order to contribute to increasing the family income, as exposed in the following account:

[...] from a very young age, they are instigated to work, it is her who gets the baby to care for, she gets everything to care for, the man always stays with the car and works away from home in order to support the home. She has to contribute to support the home and always suffering the aggression (P5-RG5).

In relation to the inequality of roles between the sexes, it falls to the man to work away from home in order to support the family, the wife, and the care for the children. The culture reinforces the role of the man working in the public space, and the woman, in the private space. One can observe the presence of the social division of the work in a classic perspective, known as sexual division of the work, because it obeys the criteria of sex. ${ }^{16}$ In the social relationships of domination, to the woman falls the work characterized as domestic; hidden, dirty, shameful and humble, while to the man, falls the official, public and dangerous work. ${ }^{14}$ Even when the woman provides for the home, she cannot see herself with autonomy in the relationship and continues to suffer aggression due to inculcated social and cultural norms. A similar situation is observed in this study, as even without contributing with activities in the home and financially, she does not feel strengthened to confront the violence. The fact of the woman working away from home and contributing to supporting the family, or even being the provider, can place tension on the relationship, as there is a change in the role of woman, which goes against the social norm which gives power to the man, which can cause violence. ${ }^{9}$

In the subcategory Absence of support when requested, according to what the professionals say, the woman in a situation of violence from an intimate or non-intimate partner requests help from close people: family members, friends, and even strangers, but the help is not always forthcoming. Generally there is omission of help on the part of the men she knows. The understanding is that, if it were a male friend requesting help, probably he would have received it. The account confirms:

[...] She asked for help, but nobody wanted to help [...]. There was a major omission, it is just that we thought that she, due to being a woman, might not have given the appropriate value to the fear she was feeling, she was in the house, she had a time for arriving in her house and she was scared of breaking that rule due to the fact of being a woman. The friend didn't want to go out with her so as not to be exposed [...]. She asked for help [he didn't help because] he had nothing to do with it, because of her being a woman. But if it had been a man there, asking for help, maybe he would've helped (P5-RG5). 
The help that the friend denied is related to the traditional gender role, showing the reiteration of the inequality and of the hierarchy existing in order to maintain the subjection and the inferiority of one sex in relation to the other. ${ }^{14}$ The request for help, initially, occurs in her social environment and the woman expects solidarity and protection, which are not always offered to her. Generally, the women discuss the violence experienced with family members and friends, however, they do not receive empathy and solidarity, this being due to the understanding of gender and family grounded in traditional models. ${ }^{17}$ Due to the cultural and moral order of male hegemony in the relationship, the women who suffer violence present ambiguous feelings, as do the people who are close to them, which causes them to ignore the occurrence, or not to believe that they should intervene, contributing to the invisibility of the gender violence. ${ }^{18}$

The woman leaves home to ask for help when she suffers severe violence and/or a threat against her life. These two situations cause her to seek the public safety services and the police, as is confirmed in the accounts:

[...] a few days ago, about a week, less than that, a case of domestic violence occurred in the area where I work. The neighbors ended up calling the ambulance service and the military police, because the woman ran out of her front garden [...] (P4-RG4).

[...] the woman suffered violence at home [...]. She didn't go to anybody apart from the police station [...] (P2-RG2).

The occurrence of violence is coupled predominantly with the home space, and in this space, the domination is male. In this aspect, the source of gender violence is the "phallocracy" fed by the culture. ${ }^{16}$ The gender violence occurs in the family space due to the absence of respect between man and woman, and can be triggered by female resistance, when she questions male authority. ${ }^{9}$ When the women leave the home, they request police protection and do not obtain it, because the safety of women is not considered a priority for these services. ${ }^{16}$ This study reinforces the idea that seeking help in the services is conditioned to the way that the woman feels the severity of the case and the need for protection, which is confirmed in another study. ${ }^{19}$

The woman who suffers violence from the intimate partner is abandoned by the family and needs to accept and put up with the situation, as the family itself blames her for the violence experienced and does not encourage her to confront the situation, as is identified in the account:

[...] the abandonment by the family, I talk about it in this sense, it often happens that the woman's own family, headed by the father, says that no, the guilty one is you, because you created this situation and provoked your husband, so you know the woman feels totally abandoned and lost in this case [...] (P4-RG4).

The conception is that the woman must put up with her situation and subject herself based on the assumption that she is obliged to tolerate aggressions of all types, because it is her destiny. In this regard, the divisions constituting the social relationships of domination are instituted between the genders based on male and female bodies, conferring on both distinct practices in the conception that it falls to women to live in a limited world, in which they "cannot become something other than what they are". 14:41 They are condemned to carry on with a socially designated identity. And the family has an important role in the reproduction and perpetuation of the male-dominated gender order. ${ }^{14}$ In this line of thought, one study shows that the mothers and mother-in-laws are considered social support of the women but that often, due to having an ambiguous conception of the situation of violence, leave the woman in doubt regarding culpability in relation to the violence and to the right to abandon the family institution. When the son hits the daughter-in-law, the mother-in-law sides with her son, does not give support to the daughter-in-law, and reinforces the idea that the marriage is indissoluble. ${ }^{10}$ The idea that the family must be maintained in any way is very resistant. ${ }^{16}$ The naturalization of the violence by the man and by the woman is owed to the social construction of gender, which is permeated by the dominant androcentric ideology. ${ }^{9}$

\section{The care practice for the woman in a situation of violence}

In the subcategory Beginning with biological care, the professionals of the EqSFs discussed the care practice in the routine and noticed that the care is initially directed to the treatment of the injuries with medications, which is expressed in the following accounts:

\footnotetext{
* In Brazil, the Military Police perform much the same function and duties as the Civil Police. Translator's note.
} 
[...] We tend to deal with the injury, the wound (P3-RG3).

[...] We're going to care, and treat the wounds (P2-RG2).

The professional practice grounded in concepts and considerations related to the general medicine courses leads to the predominance of the approach regarding the injuries or organic dysfunctions and the actions are directed to the body, without including questions related to the social and cultural environment. ${ }^{6,17}$ This tendency for care practice which is fragmented and reduced to biologicism was also identified in the study undertaken in a philanthropic maternity center, in Ribeirão Preto in the state of São Paulo. ${ }^{5}$ Another study, undertaken in the city of Matinhos in the Brazilian state of Paraná, showed that the professionals based their practices in biologizing assumptions, prioritizing the physical injuries and medicalization in acute cases. ${ }^{20}$

Care practice grounded in the biological and medicalizing model shows the basis of the training of these professionals and, because of this, the valuing of the physical complaint and of the signal in order to recognize the pathology and treat and care. In this aspect, the care practice of the woman is restricted to technical care, ${ }^{6}$ consonant with the biomedical care practice in which the diagnosis and the medication-based therapy are considered good practice. Intervening immediately in the case is always better than observing, waiting and teaching, which leads to the invisibility of the gender violence and to unawareness of the various forms of presentation in various contexts. Recognizing these certainly would require other forms of intervention, such as elaborating plans for addressing what is not pathological and appropriating the best conditions of communication, which leads to learning to work with one's own emotions and subjectivities and those of the women, requiring clear, ethical and political professional positions. ${ }^{18}$

In the subcategory Psychosocial care, in the continuity of the debate, there was the perception that, besides the care for the wound, the professionals listen, advise, encourage denunciation and refer the woman to the Mental Health Services and to the municipality's Social Services, as expressed in the accounts below:

[...] first, we have to listen to the victim [...]. We are going to be able to [...] advise, encourage the denunciation [...] (P6).

[...] We listen, advise [...] to denounce the partner [...]. We seek to refer her to the Psychology service and to the Social Services [...] (P2-RG2).
Listening, advising and embracement for the woman through a dialogue, with the construction of a shared project for confronting violence, is a practice which can lead to the resolution of the health problem. ${ }^{4}$ One study shows that the professionals perceive that they are in an ideal position for listening and encouraging the woman to speak, to give support to her without judging her. ${ }^{8}$ On the other hand, listening can be palliative, in the case of the professional hearing the woman's history and simply referring her to another service. ${ }^{17}$

Regarding the advice and encouragement to undertake a denunciation and to refer the woman to denounce, these were also practices evidenced in a study undertaken in Porto Alegre in the Brazilian state of Río Grande do Sul, with health professionals. ${ }^{17}$ This behavior shows that these professionals are following the recommendations of the World Health Organization in relation to the responsibility of the health sector, ${ }^{2}$ but, within the limits of work in the EqSFs, one can observe little focus on confronting the social determinants in an interdepartmental way. ${ }^{21}$

Regarding the referral to the psychology department, one can note the concern with the emotional aspects of the woman on the part of the professionals, reinforcing the understanding that the violence causes psychological disturbances to be attended by another health department which, supposedly, would be the responsible department. One study undertaken in São Paulo in the state of São Paulo revealed that the professionals requested the mental health services to attend women in situations of violence. ${ }^{22}$

There is a conception that this problem is relevant to the psychologists. The other health professionals identify the issue as the psychologist's work, considering that in the clinical training, these are prepared to deal with the emotional suffering of people and to identify and work with the feelings in the therapeutic relationship. In addition to this, the psychologists also integrate into their care practice actions directed towards strengthening the women, promoting their self-esteem and autonomy, elaboration of the situation of violence and the overcoming of the condition and changes in the patterns of family relationship. ${ }^{23}$

In relation to the referral to the social services, one can observe the concern with offering conditions of the social character to the woman, reinforcing that the biosocial needs are provided by another sector apart from that of health. The violence demands actions from the social services, 
with the objective of informing about the benefits which help to improve the quality of life or which contribute to coping with the violence. ${ }^{23}$ One study undertaken in health centers in Ribeirão Preto SP, showed that, after evaluating the woman's situation of risk, the health professionals refer her to the social services so that they can undertake a more detailed investigation of the situation and, following that, the case is worked on with the health team. ${ }^{24}$

The women's referral, as one of the conducts of the care practice, to specialized complementary services, configures the fragmentation of the health and social services, reinforcing the idea of division of biopsychosocial and biological needs when transformed in care practices. A similar situation was evidenced in a study undertaken in a family health care clinic in São Paulo-SP. ${ }^{22}$ On the other hand, the problem's complexity suggests a care practice exercised by a health and interdepartmental multi-professional team interacting in solving the problem. ${ }^{24}$ This reality is not always present in the PHC services, which limits the functioning of the care practices. ${ }^{6,17,20,25}$

As the discussions progressed, the professionals identified that care was given in accordance with demand, without a protocol and flow of attendance in the Family Health Centers and in the municipality's integrated health network, which is expressed in the accounts:

[...] We try to resolve the person's problem without trying to visualize how it's going to be from now onwards, because she is in need, so as not to leave her with the problem, with this shortcoming, and afterwards we go and see what to do with the others, as they appear. Today, that is the reality, it is meeting the demand (P5-RG5).

[...] attending the individual situation, trying to seek the psychologist and support, within the possibilities, but that doesn't mean to say that this is organized in a municipality, or that it is for everybody (P9).

It is observed that there are services of the PHC which also operate attending the spontaneous demand from the service users, and the actions remain in the ambit of the units. ${ }^{6}$ In the light of the evidence of cases of violence, the professionals act and feel the need to base their actions in a protocol, a condition related to the conception of the biological vision of the attendance and because of the lack of skill in the specific technologies for attending demand which go beyond the expectations of this model of care, which was also observed in the study undertaken in São Paulo - SP. ${ }^{25}$
The low quality of the professionals' technological resources for acting in situations of violence causes them to feel the need to guide the care practices through protocols, which have a sequence of actions to be undertaken. The protocol means a powerful tool for guiding the practices and gives the professionals security. ${ }^{5}$

The absence of a service organized in a network for attending women can contribute to the professionals not feeling committed to attending the demand from women in situations of violence. ${ }^{25}$

For these professionals, meeting the demand infers that the work in the ESF does not yet attend the model directed towards the health needs of the women in situations of violence. This is also observed in a study which points to the few advances made in the care practice in the ESF as a model for reorientation in the care, when one refers to the health surveillance and promotion of health, and requires a policy of interdepartmental organization. The absence of an interdepartmental health policy can leave the professionals feeling insecure in relation to the ESF's resolutive potential, as the health department, on its own, cannot address the social questions which influence the health-illness process. ${ }^{21}$

Furthermore, when - during the care practice - in listening, in addition to the violence, the women report situations such as unemployment, lack of family support, generational violence and violence extended to the children, the option of care is restricted to referrals to the social services and to the psychology service, as the account below expresses:

[...] sometimes the situation arrives, you're with the woman sitting in front of you there, speaking about much more than the violence, there is no work, there's nowhere to go, the children get hit too, the mother was hit, the father was hit, and you think: I can refer her to the psychologist, and arrange for the rent to be paid by the social services (P9).

In the cases which do not fit in the biologicist and medicalizing conception of the care practice and escape the biological processes, the professionals seek support in specialized areas of the health sector. The social problems are unlikely to be resolved in the Family Health Center. When the complaints are psychological or social, the professionals' actions are referrals, which do not always mean positive results. ${ }^{19}$ Considering the biomedical thinking of intervention, when the complaint is not specified as a disease, it is recognized as 
being a social and/or psychological matter. Pain, which goes beyond the physiological aspect, is not treated as a health need and, probably, will not be included in the care by the professionals who work in the PHC, configuring a denial of the problem of violence against the woman as part of health in the biological perspective. ${ }^{7}$ This conception inflicts restrictions of identity recognition regarding social questions as health problems. The invisibility of the violence against women and the denial of the existence as a problem also occur in the social field, marked by questions of gender which cause the violence itself. The social and gender inequities, taken as opportunities for health interventions, become a major challenge regarding mobilizing professional actions committed to human rights and the women with more fairness and gender questions. ${ }^{18}$

It can be observed that the health area has problems for acting when the questions identified are understood as cultural, social and/or psychological, however, it is necessary for the situation of violence to be embraced in the complexity which the severity of the health issue imposes, through responsible listening in which there is exposure of accessible options in the areas of safety, legal, psychological and social work, and areas of support. ${ }^{1}$

\section{FINAL CONSIDERATIONS}

The professionals of this study expressed themselves saying that in the socio-affective relationships the woman is submissive to the man and accepts, resignedly, functions such as caring for the children and the house and violent attitudes on the part of the partner. She requests help from friends and family members, but does not always obtain this due to the idea that the problem is of a domestic/private nature, and that the woman must obey the partner and remain in the situation as it is. When she feels a threat to her life, the woman requests help from the police and security departments, but this support is piecemeal.

The ideology contained in the care practice of the EqSFs was the biologistic conception directed towards medicalization, with a tendency to a broadened practice which shares the problem and the proposal for a solution with health and inter-departmental services.

The qualification of these professionals regarding gender violence can contribute to improving the care practice. The reflection on the discussion of the care practice, in the perspective of gender, can support the professionals in constructing conducts and cause them to think about mechanisms which supplant the conjugal difficulties of women and men who live in situations of violence, generated by the gender inequalities and which put relationships under tension.

The results of the study contribute to nursing professionals and professionals from the health area being able to reflect about how the care practice is provided for women in situations of violence which gives them embracement, guided by the model of social health.

\section{REFERENCES}

1. Scharaiber LB, D'Oliveira AFPL. Violência contra as mulheres: interfaces com a saúde. Interface. 1999 Ago; 3(5):11-26.

2. World Health Organization. Global and regional estimates of violence against women: prevalence and health effects of intimate partner violence and nonpartner sexual violence. Geneva (SW): World Health Organization; 2013.

3. Dieese. Departamento Intersindical de Estatística e Estudos Socioeconômicos. Anuário das Mulheres Brasileiras. São Paulo (DF): Dieese. 2011

4. D'Oliveira AFPL, Scharaiber LB, Hanada H, Durand J. Atenção integral à saúde de mulheres em situação de violência de gênero - uma alternativa para atenção primária. Ciênc Saúde Coletiva. 2009 JulAgo; 14(4):1037-50.

5. Lettiere A, Nakano MAS, Rodrigues DT. Violência contra mulher: visibilidade do problema para um grupo de profissionais de saúde. Rev Esc Enferm USP. 2008 Set; 42(3)467-73.

6. Kiss LB, Schraiber LB. Temas médicos sociais e a intervenção em saúde: a violência contra as mulheres no discurso dos profissionais. Ciênc Saúde Coletiva. 2011 Mar; 16(3):1943-52.

7. Joyner K, Mash BMC. A comprehensive model for intimate partner violence in South African primary care: action research. BMC Health Serv Res [online]. 2012 [acesso 2013 Out 01]; 12(399). Disponível em: http:/ / www.biomedcentral. com/1472-6963/12/399

8. Yeung H, Chowdhury N, Malpass A, Feder GS. Responding to Domestic Violence in General Practice: a qualitative study on perceptions and experiences. Intern J Family Medic [online]. 2012 [acesso 2013 Out 01]; 2012. Disponível em: http:/ / www.ncbi.nlm.nih.gov/pmc/articles / PMC3502852/

9. Franzoi NM, Fosneca RMGSP, Guedes RN. Violência de gênero: concepções de profissionais das equipes de saúde da família. Rev Latino-Am Enferm. 2011 Maio-Jun; 19(3):589-97. 
10. Dutra ML, Prates PL, Nakamura E, Villela WV. A configuração da rede social de mulheres em situação de violência doméstica. Ciênc Saúde Coletiva. 2013 Mai; 18(5):1293-304.

11. Brandão CR. A pesquisa participante e a participação da pesquisa: um olhar entre tempos e espaços a partir da América Latina. In: Brandão CR; Streck DR (org.) Pesquisa Participante: o saber da partilha. $2^{a}$ ed. Aparecida (SP): Idéias \& Letras; 2006. p. 20-54.

12. Le Boterf G. Pesquisa Participante: propostas e reflexões metodológicas. In: Brandão, CR (org). Repensando a Pesquisa Participante. $2^{\mathrm{a}}$ ed. São Paulo (SP): Brasiliense; 1985. p. 51-81.

13. Bardin L. Análise de conteúdo. São Paulo (SP): Edições 70; 2009.

14. Bourdieu P. A dominação masculina. 11 ${ }^{a}$ ed. Rio de Janeiro (RJ): Bertran Brasil; 2012.

15. Andrade CJM, Fonseca RMGS. Considerações sobre violência doméstica, gênero e o trabalho das equipes de saúde da família. Rev Esc Enferm USP. 2008 Set; 2(3)591-5.

16. Safiotti HIB, Gênero, patriarcado e violência. São Paulo (SP): Ed Brasil Fundação Perseu Abramo; 2004.

17. Mengehel SN, Bairros F, Mueller B, Monteiro D, Oliveira LP, Collaziol ME. Rotas críticas de mulheres em situação de violência: depoimentos de mulheres e operadores em Porto Alegre, Rio Grande do Sul, Brasil. Cad Saúde Pública. 2011 Abr; 27(4):743-52.

18. Schraiber LB, D' Oliveira AFPL, Portella AP, Menicucci E. Violência de gênero no campo da
Saúde Coletiva: conquistas e desafios. Ciência Saúde Colet. 2009 Jul-Ago; 14(4):1019-27.

19. Santi LN, Nakano MAS, Lettiere A. Percepção de mulheres em situação de violência sobre o suporte e apoio recebido em seu contexto social. Texto Contexto Enferm. 2010 Jul-Set; 19(3):417-24.

20. Signorelli MC, Auad D, Pereira PPG. Violência doméstica contra mulheres e a atuação profissional na atenção primária à saúde: um estudo etnográfico em Matinhos, Paraná, Brasil. Cad Saúde Pública. 2013 Jun; 29(6):1230-40.

21. Silva LA, Cassote CA, Chaves SCL. A produção científica brasileira sobre a Estratégia Saúde da Família. Ciênc Saúde Colet. 2013 Jan; 18(1):221-32

22. Guedes RN, Fonseca RMGS, Egry EY. Limites e possibilidades avaliativas da estratégia saúde da família para a violência de gênero. Rev Esc Enferm USP. 2013 Abr; 47(2):304-11.

23. Hanada H, D'Oliveira AFPL, Schraiber LB. Os psicólogos na rede de assistência a mulheres em situação de violência. Rev Estud Fem. 2010 Jan- Abr; 18(1):33-59.

24. Vieira EM, Ford NJ, Ferrante FG, Almeida AM, Daltoso D, Santos MA. The response to gender violence among Brazilian health care professionals. Ciênc Saúde Coletiva. 2013 Mar; 18(3):681-90.

25. Osis MJD, Duarte GA, Faúndes A. Violência entre usuárias de unidades de saúde: prevalência, perspectiva e conduta de gestores e profissionais. Rev Saúde Pública. 2012 Abr; 46(2)451-8. 